\title{
A justiça do trabalho
}

Regina Lucia M. Morel e Elina G. da Fonte Pessanha

$\mathrm{N}$ asúltimas décadas, cientistas sociaistêm sedebruçado sobrea relação entre o protagonismo do Poder Judiciário ea consolidação de regimes democráticosconstitucionais, tanto no quediz respeito àmediação de conflitos como à proteção de direitos. Assim, pesquisas sobre as instituições e os atores do mundo jurídico somam-sea análises dos graus e das formas deacesso àjustiça, da relação entre instituições judiciárias e democracia, do pluralismo normativo e das formas alternativas de resolução de conflitos, bem como da efetividade do direito na prevenção de conflitos.

Também no Brasil multiplicaram-se as pesquisas empíricas na área das ciências sociais sobre o mundo jurídico e sua relação com a sociedade, sobretudo após a democratização e a Constituição de $1988^{1}$. A Justiça do Trabalho, no entanto, tem sido pouco estudada pelo mundo acadêmico, 1. Ver M orel ePessanha (2006). lacuna surpreendente sobretudo se levarmos em conta a filiação trabal hista de nossa cidadania social.

Campo de lutas, al vo de disputa em torno de modelos diferenciados de sociedade e de institucionalização das relações capital/trabalho no Brasil, a Justiça do Trabalho foi, na última década, ameaçada sem sucesso por projetos de governo que previam transformações profundas ou mesmo sua extinção. N este texto, pretendemos destacar a especificidade desse ramo da justiça, apontando para al gumas particularidades do perfil de seus magistrados. Procuraremos também refletir sobre as perspectivas e os princi- 
2. Ver C astro Gomes, Pessanha e Morel (2004) e M orel, Castro $\mathrm{G}$ omes e Pessanha (2007).

3.0 índice de respostas ao survey foi de $17 \%$, embora em alguns estados, como Rio deJ aneiro, tenha superado os $30 \%$ e, em São Paulo e M inas Gerais, os $20 \%$. A amostra foi controlada a fim degarantir sua representatividade. $\mathrm{N}$ a fase de tabulação e análise dos dados quantitativos, contamos com a consultoria do professor Carlos Antonio Costa Ribeiro (UERJ/luperj). pais desafios enfrentados pelos magistrados do trabal ho na atualidade. N ossas observações baseiam-se em resultados do projeto "H istória da justiça e dos direitos do trabalho no Brasil", pesquisa interinstitucional (CPD O C/FGV e IFCS-U FRJ), coordenada pelas autoras deste texto e pela professora Ângela M aria do Castro Gomes, desenvolvida com apoio do Pronex e de Edital U niversal do CN Pq. N uma primeira etapa, investimos na reconstituição da história por meio principalmente do depoimento de dois personagens centrais de sua construção, Arnaldo Sussekind e Evaristo de M oraes Filho². Em 2005, realizamos um abrangente survey "Perfil da magistratura do trabalho" - , enviando questionários para mais de 3 mil magistrados do trabal ho - entre ativos e inativos - do país ${ }^{3}$. A finalidade foi traçar o perfil sociológico dos juízes, assim como registrar suas percepções sobre a carreira e o papel desempenhado por sua instituição na sociedade brasileira.

\section{Uma justiça especial}

N unca é demais lembrar que a implantação da Justiça do Trabalho em 1941, assim como a consolidação da legislação trabal hista em 1943, sucede um longo processo, iniciado antes mesmo da República, delutase conquistas de direitos por parte dos trabalhadores. M uitas vezes propostas pelos chamados reformadores sociais - partidários ou não - , as primeiras leis trabal histas surgem de modo esparso, como as de proteção ao trabalho do menor, em 1891. D e 1903 éalei de sindicalização rural e de 1907, a lei que regulou a sindicalização de todas as profissões. 0 primeiro projeto de Código do Trabalho, de M aurício de Lacerda, tentativa malsucedida de reunir e sistematizar a legislação pertinente, é de 1917. Em 1918, Lacerda aprovou na Câmara o projeto do D epartamento N acional do Trabalho, órgão que acabou substituído pelo Conselho $\mathrm{N}$ acional do Trabalho cinco anos depois. De 1919 é a lei sobre acidentes de trabalho. De 1923, a lei Eloy C haves, que criou caixas de aposentadoria e pensões nas empresas de estradas de ferro, depois estendidas a outros setores. Em 1926, com a R eforma Constitucional, pela primeira vez passa a constar numa Constituição do país "como assunto expresso" a referência à legislação do trabalho. N o plano propriamente jurídico, as primeiras funções específicas de "justiça do trabalho" no Brasil couberam aos tribunais rurais do estado de São Paulo, instituídos pelo então governador Washington Luiz, em 1922, para dirimir conflitos entre patrões e colonos, decorrentes principal mente dos efeitos da 
imigração e da presença de trabal hadores estrangeiros mais politizados (cf. M oraes Filho, 1982).

A Revolução de 1930 acelera o processo de regulação e de montagem de uma nova estrutura para gerir as relações trabal histas. Já em 1930, cria-se 0 M inistério do Trabalho, cujo primeiro consultor jurídico, Evaristo de M oraes, redige, com Joaquim Pimenta, em 1931, o D ecreto n. 19.770, que tinha por objetivo regular "a sindicalização das classes patronais e operárias". $\mathrm{N}$ o mesmo ano instala-se o novo $\mathrm{D}$ epartamento $\mathrm{N}$ acional do Trabalho, junto ao qual, em 1932, passam a funcionar as Comissões M istas de Conciliação eas Juntas deC onciliação e Julgamento ${ }^{4}$. A C onstituição de 1934 finalmente institui a Justiça do Trabal ho (título IV, art. 122) "para dirimir questões entre empregadores e empregados, regidas pela legislação social". Assegura-seentão o estatuto da pluralidade sindical ea completa autonomia dos sindicatos, vários di reitos são regulados, como a jornada diária (oito horas), esão reconhecidas também as convenções coletivas. A composição dos tribunais de trabal ho e das comissões de conciliação devia obedecer ao princípio de eleição paritária de representantes de patrões e empregados, com presidenteindicado pelo governo.

Em 1936, um anteprojeto de organização da Justiça do Trabal ho, elaborado por técnicos do M inistério do Trabalho, pelo seu consultor jurídico, O liveira Viana, epela Procuradoria do Trabalho, éencaminhado pelo presidente G etúlio Vargas ao Poder Legislativo, e o debate sobre essa proposta expõe um quadro de fortes disputas políticas e ideológicas em torno do caráter da instituição, tanto dos interesses conflitantes em jogo, como deadesões a seus pressupostos e objetivos.

Assim, de um lado, é possível caracterizar o modelo varguista de relações de trabalho, considerando que ele não só respondia a demandas sociais já existentes ${ }^{5}$, mas também estava referido ao que pode ser entendido como um "consenso antiliberal", apoiado numa verdadeira concordância entre as correntes: socialistas, católicose corporativistas, todos comprometidos, embora com objetivos e estratégias diferenciados, com a correção das desigualdades sociais da ordem capitalista por meio da ação do Estado ${ }^{6}$.

D eoutro lado, tem-sea fortereação liberal à proposta apresentada, deque é exemplar a atuação, como relator, do renomado advogado civilista paulista Wal demar Ferreira na Comissão de Constituição ej ustiça do C ongresso $\mathrm{Na-}$ cional. 0 sliberaisnão queriam umajustiça federal - tão distanteeacima dos interesses locais bem sedimentad os. $N$ ão queriam também que os sindicatos funcionassem como pessoas jurídicas públicas, al egando quea vontade indi-
4. As C omissões M istas de Conciliação, incluindo seis representantes detrabalhadores e seis de patrões, tinham por finalidade tentar conciliar impasses coletivos; as Juntas de Conciliação eJulga mento (um representantedostrabalhadores, um dos patrões, um bacharel) tinham poderes para julgar as questões trabal histas individuais.

5. Ver, nesse sentido, os trabalhos de M oraes Filho (1978) e Castro Gomes (1994), críticos da tese da outorga.

6. Para a Igreja católica, a questão social era assunto de compromisso cristão para com os pobres. A encíclica Quadrages mo Anno, de Pio XI, de 1931, reforçando os princípios da Re rum N ovarum, de Leão XIII (1891), recomendava: ao capital, tratar os pobres deforma humanitária; aostrabalhadores, serem moderados; e ao Estado, promover aintervenção sob estatuto ético-moral e jurídico. Para os socialistas, a intervenção estatal era central para as reformas sociais, contra a dominação dospatrões sobreostrabalhadorese 
suasassociações. Q uanto aos corporativistas, quelideravam o processo, argumentavam que osconflitosentreempregadores e empregados não eram meramentede interesse privado "como no velho e morto liberalismo, mas que o Estado devia intervir neles, sob uma constituição onde a ordem econômica seja submetida à disciplina do Estado" (Morel e Pessanha, 2006).

7. A Emenda Constitucional n. 24, de dezembro de 1999, extinguiu os juízes classistas. vidual dos trabalhadores deveria prevalecer. $\mathrm{N}$ ão aceitavam, na verdade, a existência desujeitosedireitos coletivos, enão queriam umaJ ustiça do TrabaIho com o que consideravam o poder de legislar: eram frontal mente contra o poder normativo. Somenteapós 1937, jáno Estado N ovo deVargas, o conflito foi decidido, ecom isso implantou-seo modelo derelações detrabal ho que, embora com al gumase profundasalterações, estáaí atéhoje, equetem najustiça do Trabal ho um deseus pontos desustentação fundamentais.

A Constituição de 1937 mantém a Justiça do Trabalho, mas introduz mecanismos de enrijecimento da estrutura sindical e de seu controle, como a unicidade, o imposto compulsório, o enquadramento sindical. Regulada em 1939 e regulamentada em 1940, a Justiça do Trabalho inaugura-se finalmente em 1941. Coube a Francisco Barbosa de Resende, quinto presidente do Conselho $\mathrm{N}$ acional do Trabalho, presidir a comissão especial incumbida de organizar einstalar a Justiça do Trabal ho, o que ocorreu no dia 1 - de maio de 1941, no campo de futebol do Vasco da Gama, no Rio de Janeiro, em ato público presidido por $\mathrm{G}$ etúlio Vargas.

$\mathrm{N}$ a estrutura do $\mathrm{M}$ inistério do Trabalho, como justiça administrativa, a Justiça do Trabal ho ficou estruturada em três instâncias. $\mathrm{N}$ a base, as J untas deC onciliação e Julgamento (JC J s), que mantiveram o nome ea composição, com a diferença de que seu presidente passava a ser um juiz de direito ou bacharel nomeado pelo presidente da República para mandato de dois anos. Atuavam também os chamados juízes classistas, representantes de trabalhadores e patrões. Os "classistas "eram indicados pelos sindicatos, para mandatos também de dois anos?. Em nível intermediário, os Conselhos Regionais do Trabalho, com a função de deliberar sobre recursos. $E$, em nível superior, o Conselho $\mathrm{N}$ acional do Trabalho, integrado por dezenove membros nomeados pelo presidente da República para mandatos de dois anos, permitida a recondução, e assim distribuídos: quatro representantes de empregados, quatro de empregadores, quatro funcionários do M inisté rio do Trabalho e das instituições de seguro social, e sete pessoas de reconhecido saber, das quais quatro formadas em direito.

As 36 Juntas de Conciliação e Julgamento estavam distribuídas em oito regiões, onde funcionavam os $C$ onselhos Regionais, a saber: $1^{\underline{a} \text { R }}$ egião, Rio de Janeiro; 2ª Região, São Paulo; 3ª, Belo H orizonte; 4a , Porto Alegre; 5a,

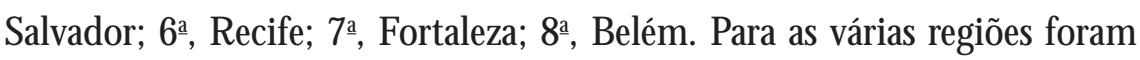
nomeados também procuradores regionais da Justiça do Trabalho.

É essa justiça, ainda com sua natureza jurídica pouco definida, que irá controlar, a partir de 1943, o cumprimento da Consolidação das Leis do 
Trabalho, a CLT. Apenas na Constituição de 1946 a Justiça do Trabalho torna-se efetivamente parte do Poder Judiciário, autônoma em relação ao Poder Executivo em todos os níveis, com competência específica, poder normativo eM inistério Público correspondentejunto ao M inistério Público da União. A carreira de juiz do trabalho passava a seguir o modelo da carreira da magistratura em geral, sendo composta de três níveis: juiz presidente de vara, juiz do Tribunal Regional do Trabalho (desembargador) e ministro do Tribunal Superior do Trabalho. No entanto, como lembra Roberto Fragale, foi longo o caminho até que os juízes do trabal ho construíssem uma identidade institucional efossem aceitos como integrantes do Poder Judiciário ${ }^{8}$. Também demorou décadas para que a equiparação dos vencimentos garantisse aos juízes do trabal ho os mesmos direitos e prerrogativas dos demais membros do judiciário.

Inserida no âmbito da Justiça Federal e, portanto, menos atreladaa interesses locais, a ustiça do Trabal ho surge marcada pela natureza intervencionista e protecionista do Estado e, para isso, pretendia tutelar o trabal hador, definido como "economicamentemaisfraco". Com esses objetivos, desde o início o processo trabalhista apresenta certas características mantidas até hoje, como a gratuidade de seus custos, a dispensa de advogados, a oralidade ${ }^{10}$ e a maior informal idade. $0 \mathrm{~s}$ atos processuais mais relevantes são real izados na audiência, ao contrário do que ocorre no processo civil. Além disso, o processo trabalhista tem caráter conciliatório, isto é, o juiz deve envidar todos os esforços para conseguir fazer com que as partes conciliem antes da apresentação da defesa ou depois de encerrada a instrução.

As principais características da J ustiça do Trabal ho, com sua forte marca antiliberal de origem, permaneceram, e ela se mostrou capaz de sobreviver a várias mudanças político-institucionais. Assim, por exemplo, o regime autoritário de 1964 estrategicamente suspendeu al guns direitos importantes, como a estabilidade, e reforçou o uso dos aspectos repressivos já contidos na legislação vigente desde 1943. A pesar disso, há muitas indicações de que a Justiça do Trabal ho, cuja estrutura permaneceu a mesma na Constituição de 1967 e não foi alterada pela Emenda Constitucional de 1969, representou, durante esse período autoritário, um dos poucos espaços de defesa de direitos sociais.

$\mathrm{N}$ a segunda metade da década de 1980, segmentos de trabalhadores organizados em torno do "novo sindicalismo" lideram uma fase de explosão de demandas trabal histas, por meio de greves, negociação direta com 0 patronato, maior prioridade aos problemas nos locais de trabal ho, organi-
8.0 primeiro concurso público deu-se em 1959.

9.Segundo Fragale (2006), "a Justiça do Trabalho eraamais desprezada e relegada do sistema federal de justiça".

10. 0 processo do trabalho é eminentemente oral, isto é, nele pre valecea palavra "falada", ao contrário do processo civil, em que quase todas as pretensões são formuladas por petições escritas. Em razão desse princípio, o processo desenvolve-se principalmente na audiência, assegurando um contato estrito entreas partes e com o magistrado, fato fundamental para a imediatidade da decisão.

novembro 2007 
11.Em 2006, elas alcançaram um total de 1.109 varas.

12. A Emenda Constitucional n. 45 foi publicada em 8 de dezembro de 2004. zação de comissões de fábrica. U tilizando dados referentes à expansão das varas de trabalho, Adalberto Cardoso (2002) chamou a atenção para dois fatos: primeiro, cada pico de demandas foi acompanhado da criação de novas varas de trabalho, indicando que a estrutura da justiça trabalhista tem respondido à expansão das reclamações; segundo, o aumento considerável da procura da Justiça do Trabalho na década de 1990 pode ser visto como reação à precarização das condições de trabalho e às tentativas dos empregadores de burlar as normas legais no que diz respeito a direitos rescisórios. $\mathrm{O}$ u seja, indiferentes a todas as críticas e opiniões desabonadoras à Justiça do Trabalho, os trabalhadores continuaram vendo nela um aliado na defesa de seus direitos. 0 confronto político expressou-se nesse período, sem contudo pôr inteiramente em xeque os vel hos estatutos. C resce também de modo significativo nesse momento o número de juízes e, segundo o princípio de interiorização dos serviços, novas varas possi bilitam um acesso cada vez maior à Justiça do Trabalho"1.

É esse o pano de fundo do período de transição e do processo constituinte de 1988, época em que se registra o primei ro ensaio de atuação conjunta dos magistradose das forças políticas de outros poderes. A nova Constituição não mudou a Justiça do Trabalho, mas estabeleceu que em cada unidade da federação haveria pelo menos um Tribunal Regional do TrabaIho (TRT ). 0 número de regiões do trabalho expandiu-se então de quinze para 24, cobrindo todos os estados da federação. 0 representante classista da 1a instância (JCJs) passou também a ser identificado como juiz classista, e não mais como vogal.

Preconizando o "fim da era Vargas", o governo Fernando H enriqueC ardoso (1994-2002) investiu duramente contra o modelo tradicional de relações trabal histas, chegando mesmo a propor a extinção da Justiça do TrabaIho. Várias inovações legislativas foram sendo tentadas e, embora al gumas terminassem de fato por flexibilizar formas de contratação e propiciar novos espaços de negociação trabal hista, a Justiça do Trabalho escapou ilesa, graças à firme reação das associações profissionais do setor jurídico e de sindicatos dos trabalhadores.

Recentemente, no entanto, a aprovação da chamada Reforma do Judiciário reforçou o papel da Justiça do Trabalho, ampliando sua competência sobre todas as relações trabalhistas ${ }^{12}$. D e fato, até a publicação da Emenda n. 45, a Justiça do Trabal ho tinha por finalidade apenas apreciar os conflitos decorrentes das relações de emprego, isto é, aquelas relações formais, com "carteira assinada", regi das pela C LT. Pela nova redação do artigo 114 
da C onstituição, no entanto, compete à Justiça do Trabalho "processar e julgar as ações oriundas da relação de trabalho". M as, por outro lado, a reforma reduziu sensivelmente o poder normativo da Justiça do Trabal ho, isto é, a capacidade de estabelecer novas condições detrabal ho, medida essa que veio no sentido de privilegiar a livre negociação entre as partes, dificultando a intervenção do Estado em conflitos coletivos.

Os magistrados do trabalho, entre a tradição e a mudança ${ }^{13}$

O s principais operadores da Justiça do Trabalho, atuantes em todo 0 território nacional, são hoje 2.719 juízes distribuídos nas três instâncias da

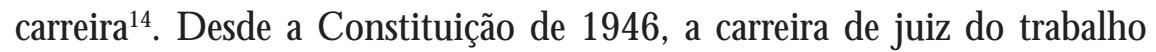
segue o modelo da carreira da magistratura em geral, sendo composta de três níveis: juiz presidente de vara, juiz do Tribunal Regional do Trabalho e ministro do Tribunal Superior do Trabal ho. Regulamentadas pela Lei Complementar da M agistratura (Loman), de 14 demarço de 1979, epela Constituição de 1988, as promoções obedecem aos critérios de antiguidade e merecimento ${ }^{15}$; para os tribunais, os magistrados são nomeados pelo presidente da República, que escolhe a partir de uma lista tríplice. Antes de tornar-se titular de uma vara, o aprovado no concurso énomeado juiz substi tuto e passa por um estágio probatório de dois anos para só então alcançar a vitaliciedade.

Como já identificado por outros estudos sobre magistrados, ocorreu recentemente no Brasil uma redefinição também do perfil social dos juízes do trabalho. Como o Gráfico 1 comprova, os juízes do trabalho são hoje mais jovens, já que, segundo dados do TST referentes a 2004, 50\% deles têm menos de quarenta anos ${ }^{16}$. Isso significa que a formação universitária nos cursos de direito desses magistrados se deu no contexto político da democratização da sociedade brasileira e do debate que antecedeu a Constituição de 1988. U ma importante questão a ser analisada nas respostas ao survey ése se pode falar em perfis geracionais distintos entre os magistrados do trabalho, bem como se aqueles que setornaram bacharéis no período de democratização têm percepções distintas sobre o papel social da categoria comparativamente aos mais velhos.

A par da juvenilização dos magistrados, tem-se registrado também a feminização acentuada da categoria: a participação das mulheres alcança $43 \%$ dos juízes de primeiro grau e $36,5 \%$ nos tribunais ${ }^{17}$. É isso que se pode observar no Gráfico 2, construído também com dados do TST, que
13. Análise bem mais completa dos dados aqui apresentados está em Castro Gomes, Pessanha e M orel (2007).

14. N asúltimas décadas tem havido um expressivo crescimento da ca tegoria. De 1995 a 2003, por exemplo, a quantidade dejuízes do trabalho cresceu $37,6 \%$. Em 2003 eram 2.068 juízesno primeiro grau, distribuídos em 1.251 varas. Os desembarga dores dos TRTs eram 440 e havia dezessete ministros no TST. Pela Reforma do Judiciário aprovada em dezembro de 2004 (Emenda Constitucional n. 45), esse número aumentou para27 (dadosdoT ST).

15. A fim detornar mais objetivo o critério de merecimento, a Constituição de 1988 determinou que os candidatos devem integrar a primeira quinta parte da lista de antiguidade quanto a esse critério. Aos tribunais caberia formar a lista com três nomes, considerando os critérios de segurança e presteza no exercício jurisdicional, além dafreqüência a cursos de reconhecido aperfeiçoamento profissional. 
16. Pela Reforma do Judiciário, para serem aprovados nos concursos os candidatos devem comprovar três anos de atividade jurídica.

17. Esse aumento da participação feminina não se restringe à ma gistratura eéobservado em todas as profissões jurídicas, ainda que Bonelli (2002) argumente que, apesar do crescimento do número de advogadas, elas se concentram nos ramos menos prestigiados do direito civil (família, direitos sociais, trabaIhistas e pequenas causas). Também namagistratura do trabalho, 0 posto mais elevado da carreira, M inistro do Tribunal Superior do Trabalho, aindaéessencialmente masculino, embora se perceba al guma alteração mais recente. Antes da vigência da EmendaC onstitucional n. 45, de2004, entreos dezessete ministros do TST havia apenas uma mulher, correspondendo a $5,9 \%$ do conjunto; hoje, entre as vinte vagas ocupadas, quatro são por mulheres(20\%). permite visualizar uma série histórica de 1995 a 2003, corroborada pelos dados de nossa amostra de 2005.

GRÁFICO 1

Justiça do Trabalho no Brasil: Distribuição de Juízes por I dade

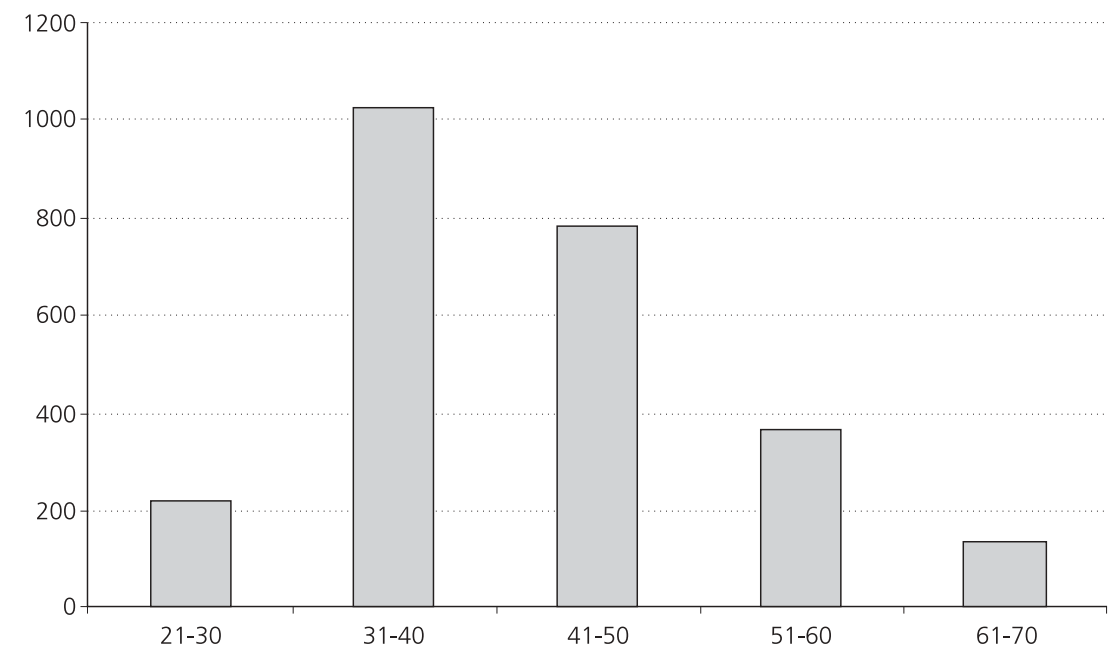

Fonte: Site www.TST.org.br, acessado em 10/7/2005.

GRÁFICO 2

Justiça do Trabalho no Brasil: N úmero de Juízes por G ênero

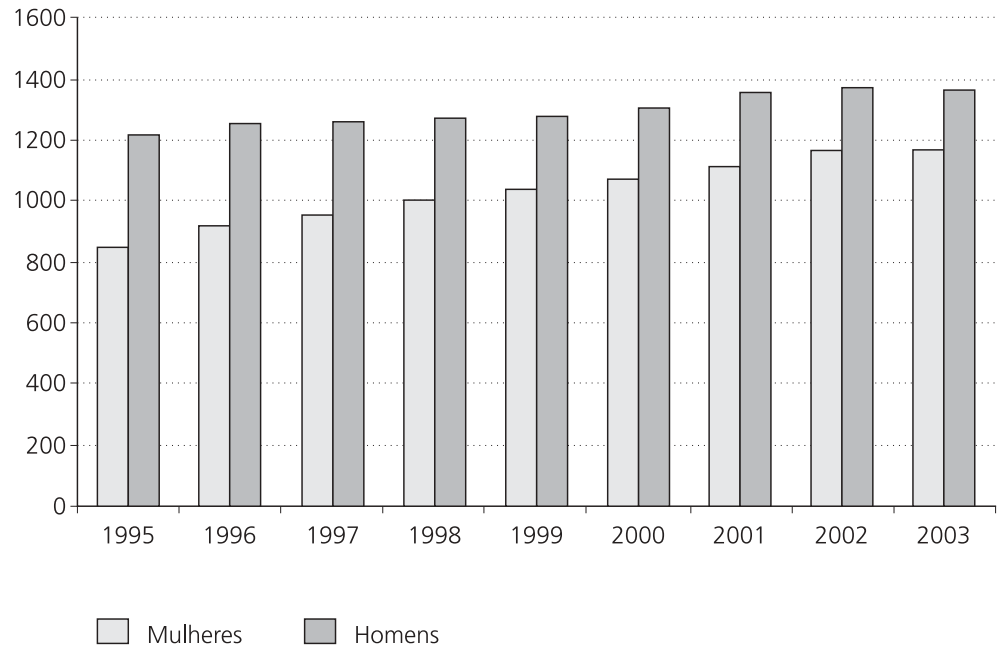

Fonte: Site www.TST.gov.br, acessado em 10/9/2005. 
Essa tendência de crescimento do número de juízas destaca-se ainda mais quando os dados de gênero da Justiça do Trabal ho, colhidos pelo survey sobre o Perfil da M agistratura do Trabal ho, são comparados com os obtidos por pesquisa encomendada pela Associação dos M agistrados do Brasil sobre os juízes de todos os ramos do judiciário, como se observa no G ráfico $3^{18}$.

\section{GRÁFICO 3}

Comparação de $G$ ênero entre Justiça do Trabalho e os 0 utros Ramos do Judiciário

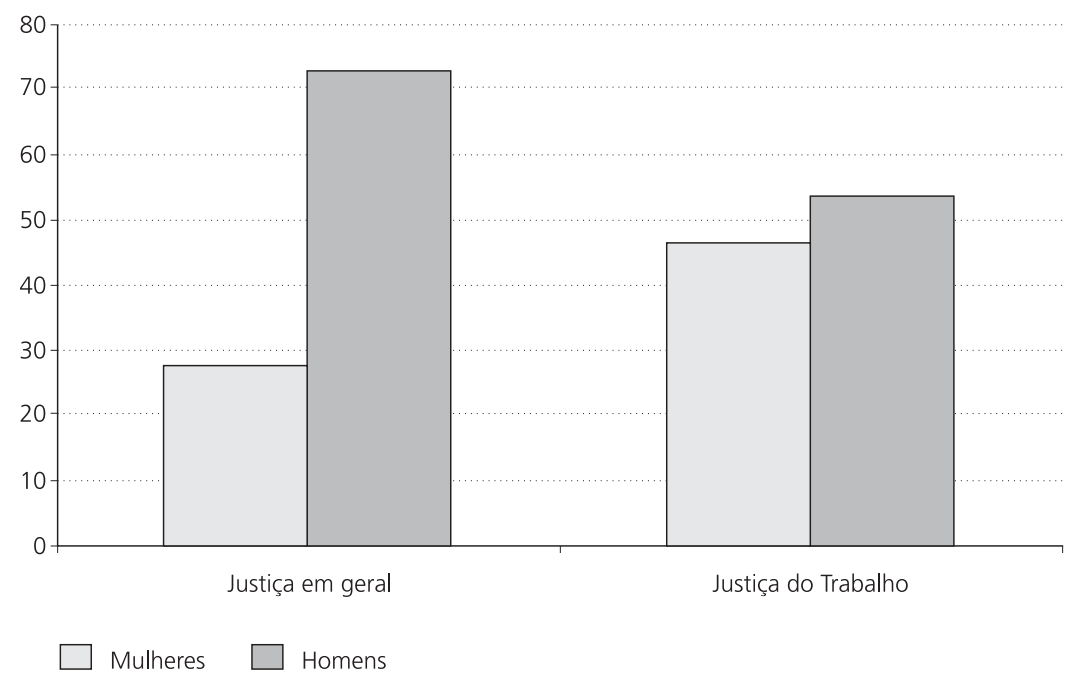

Fontes: Pesquisa AM B, 2005; Pesquisa "Perfil da M agistratura do Trabalho no Brasil".

Como se pode observar, os dados para a justiça em geral indicam uma presença proporcional mente bem menor de mulheres entre seus quadros.

0 utra tendência registrada por nossa amostra refere-se à mobilidade social dos juízes em relação a seus pais, e revela que os magistrados vêm de diferentes estratos da sociedade brasileira. U m primeiro conjunto de informações refere-se à escolaridade de pais e mães dos juízes.

0 que se pode observar é que mais de $40 \%$ dos pais e mães dos juízes ouvidos não concluíram o 9o ano do Ensino Fundamental, e mais de 8\% dos pais e $6 \%$ das mães não têm nenhuma série completa. N o outro extremo do quadro, pouco mais de $30 \%$ dos pais e menos de $20 \%$ das mães têm instrução superior.

0 utro conjunto de informações remete à ocupação dos pais dos magistrados. $0 \mathrm{~s}$ dados estão classificados por cinco grupos ocupacionais, e no primeiro grupo foram destacadas as profissões de juiz e advogado.
18. Ver Sadek (2006). A comparação entre esses dados foi realizada, sob nossa supervisão, pelos bolsistas de Iniciação Científica do CN Pq/ Pibic-U FRJ Luisa Pe reira eD aniel Iliescu, e apresentada na Jornada deIniciação Científica da UFRJ em 2006. 
GRÁFICO 4

Escolaridade dos Pais dos Juízes Entrevistados

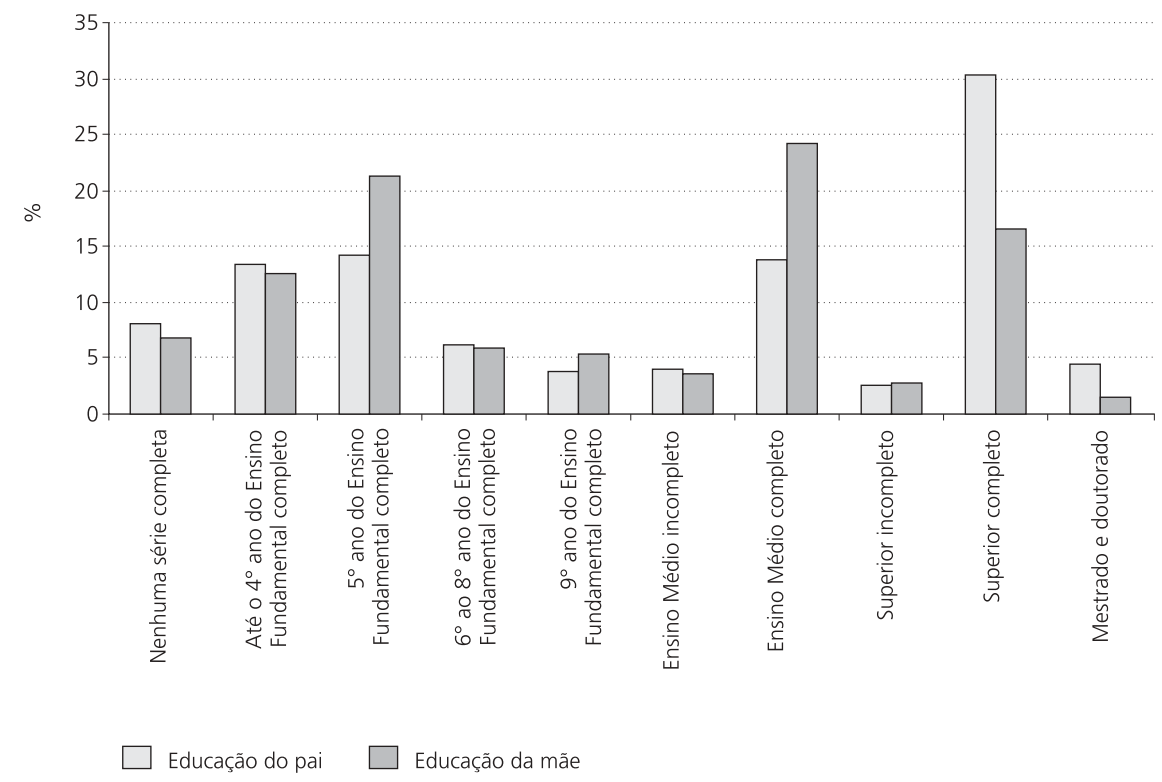

Fonte: Pesquisa "Perfil da M agistratura do Trabalho no Brasill".

TABELA 1

0 cupação dos Pais dos J uízes do Trabal ho

\begin{tabular}{|c|c|c|c|}
\hline O CUPAÇÃO DO PAI & \multicolumn{2}{|c|}{$\%$} & $\mathrm{~N} \stackrel{0}{2}$ \\
\hline PROFISSIONAIS E ADM INISTRADORES & $22,6 \%$ & & 98 \\
\hline JUIZ & $6,0 \%$ & $34,1 \%$ & 26 \\
\hline ADVOGADO & $5,5 \%$ & & 24 \\
\hline TRABALHAD ORES NÃO MANUAIS DE ROTINA, ESCRITÓRIO & $24,4 \%$ & $34,8 \%$ & 106 \\
\hline PROPRIETÁRIOS E COM ERCIANTES, PEQUEN OS NEGÓCIOS & $10,4 \%$ & & 45 \\
\hline TRABALHAD ORES MANUAIS & $21,2 \%$ & $31,1 \%$ & 92 \\
\hline TRABALHAD ORES RURAIS, PEQUEN OS PROPRIETÁRIOS RURAIS & $9,9 \%$ & & 43 \\
\hline TOTAL & $100,0 \%$ & & 434 \\
\hline
\end{tabular}

Fonte: Pesquisa "Perfil da M agistratura do Trabalho no Brasil".

A análise desses dados mostra, em princípio, a distribuição bastante equilibrada da ocupação dos pais dos juízes, principalmente se agrupadas em três níveis diferenciados em termos de renda e capital social, quando os percentuais aparecem sempre em torno dos 30\%. M erece destaque, nesse sentido, o número de juízes com pais nos níveis considerados mais baixos de ocupação, que teriam realizado um esforço maior de mobilidade social.

Ainda que os dados de nossa amostra demonstrem, portanto, uma relativa abertura social da carreira em termos de idade, gênero e origem social, 
eles expressam também que a barreira da cor continua sendo um fator de terminante de exclusão em nossa sociedade: $86 \%$ dos magistrados do trabalho se declara de cor branca, em contraponto a apenas cerca de $10,8 \%$ de cor parda e 1,2\% de cor preta.

\section{GRÁFICO 5}

D istribuição Percentual de Cor ou Raça dos]uízes Entrevistados

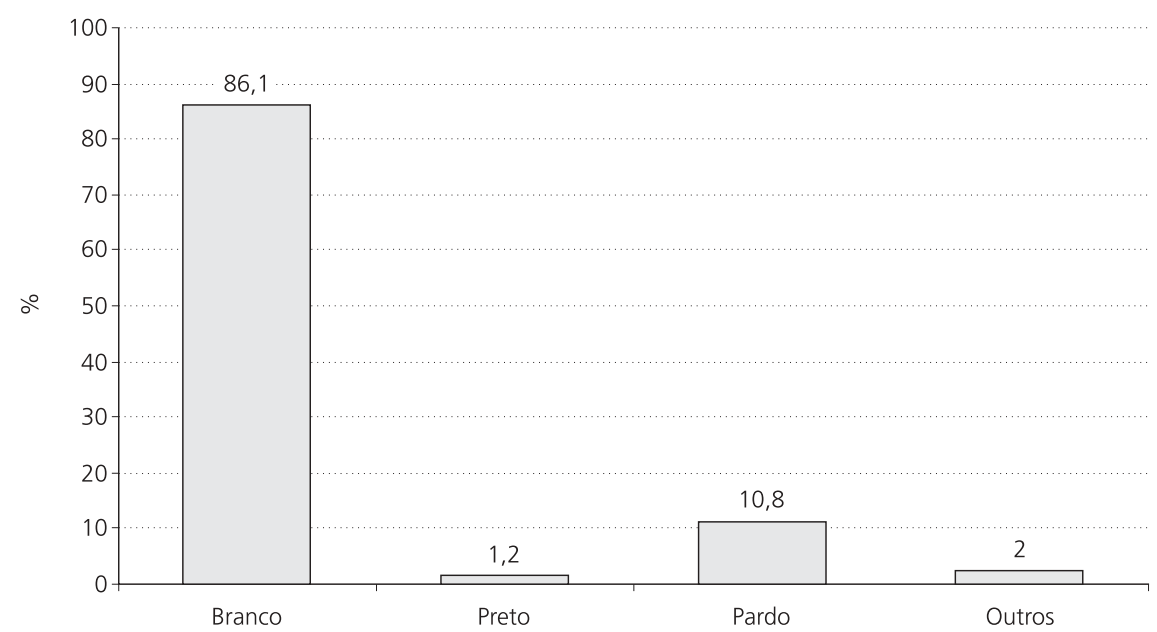

Fonte: Pesquisa "Perfil da M agistratura do Trabalho no Brasil".

GRÁFICO 6

Atividade Associativa

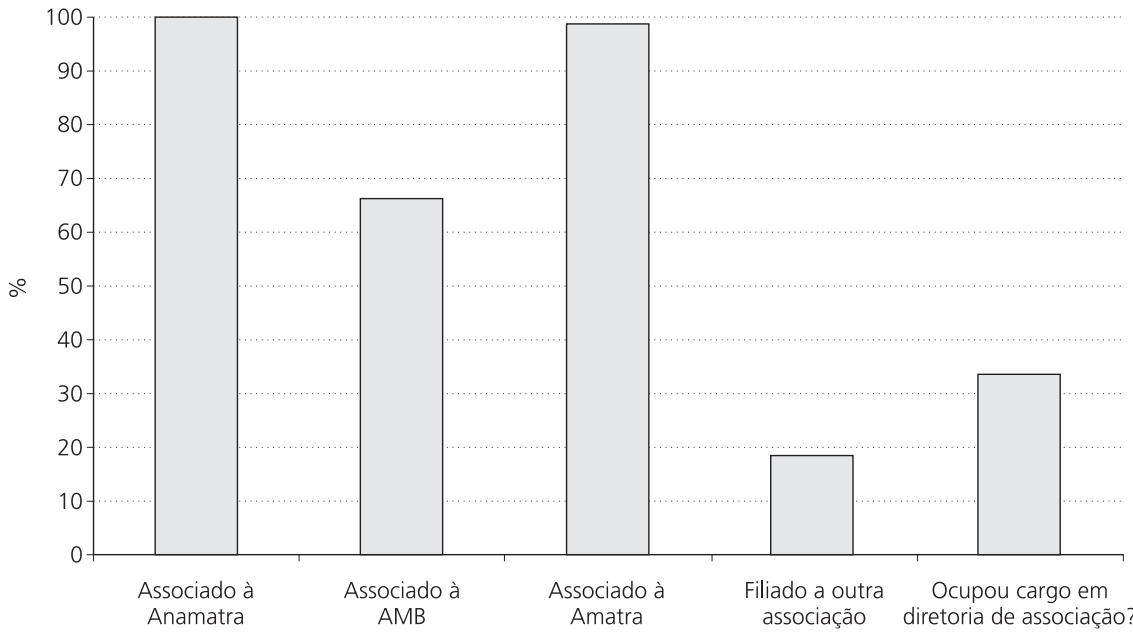

Fonte: Pesquisa "Perfil da M agistratura do Trabalho no Brasil".

Ao ingressarem na carreira, os juízes do trabal ho passam por um processo importante de socialização, em parte nas Escolas de M agistratura e em 
19. A associação nacional da categoriafoi criada em 1976, a partir da articulação deentidades estaduais já existentes, e sua primeira diretoria foi eleita em 1978.

20. Em muitos estados, a visita à sede das Amatras pelos recém-concursados, acompanhada do convite para que se associem, é um importante rito de iniciação na profissão. parte on the job, sob rígido controle dos respectivos Tribunais Regionais. Essa socialização é complementada por forte adesão a um associativismo ativo e profundamente comprometido com a instituição e seus princípios. As respostas ao survey comprovaram o al to grau de associativismo dos juízes do trabalho: como se pode observar no Gráfico 6 , mais de $98 \%$ deles são filiados à Anamatra (Associação $\mathrm{N}$ acional dos M agistrados do Trabal ho) ${ }^{19}$, porcentagem que certamente a maioria das associações de classe e sindicatos invejariam, mesmo considerando-se que tal filiação é hoje quase uma prática cultural obrigatória20.

Esse associativismo tem refletido crescentemente as aspirações de democratização interna da carreira, como também de uma maior intervenção "externa", como tão bem se revelou na luta da instituição contra o trabal ho análogo ao escravo.

\section{GRÁFICO 7}

O pinião sobre Promoção para Juiz T itular por Regi ão de Atuação

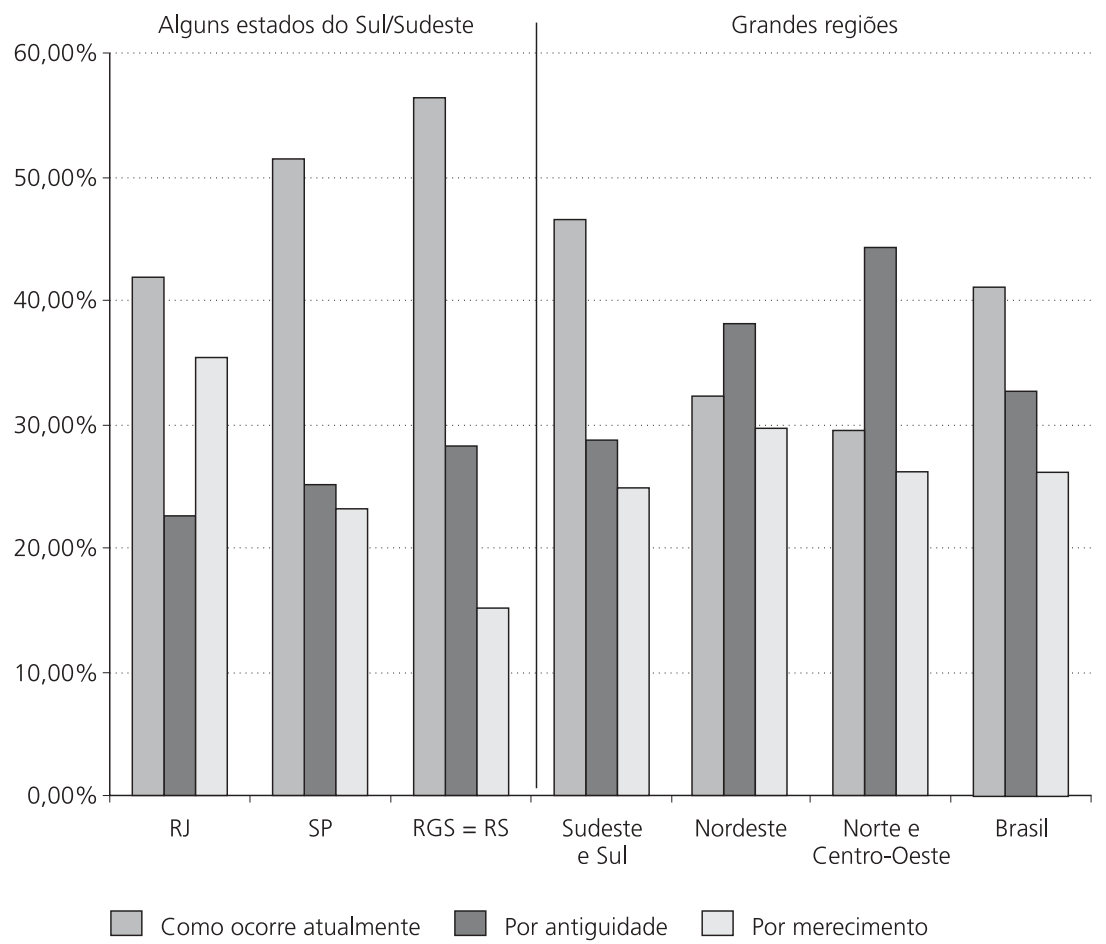

Fonte: Pesquisa "Perfil da M agistratura do Trabalho no Brasil".

Em relação à carreira, os juízes opinaram sobre se gostariam de manter as regras de mobilidade definidas por lei e utilizadas atualmente - alternando 
entre uma promoção por merecimento e outra por antiguidade-, ou se prefeririam que fossem adotados novos critérios. H ouveal gumas divergênciase, para efeito de ilustração, parte dessas informações processadas foi aqui agrupada em três grandes regiões do país (N orte/C entro-O este, Sudeste/Sul e N ordeste), com destaquetambém paratrêsestados daregião Sudeste/Sul: Rio de Janeiro (1 $1^{a}$ região trabalhista), Rio G rande do Sul (4a) e São Paulo - este compreendendo as regiões trabal histas deSão Paulo (2ª eC ampinas (15a) ${ }^{21}$.

No que se refere à primeira promoção possível da carreira, de juiz substituto para juiz titular de uma vara trabal hista, os juízes que atuam no $\mathrm{N}$ orte/C entro-O esteeno $\mathrm{N}$ ordestemanifestaram-se preferencial mente pelo critério de antiguidade (respectivamente, $44 \%$ e $38 \%$ por região). Já os juízes do Sudeste/Sul preferem que se mantenha a promoção nos moldes em que ela ocorre atualmente $(46 \%)$.

GRÁFICO 8

0 pinião sobre Promoção para oT RT por Regi ão de Atuação

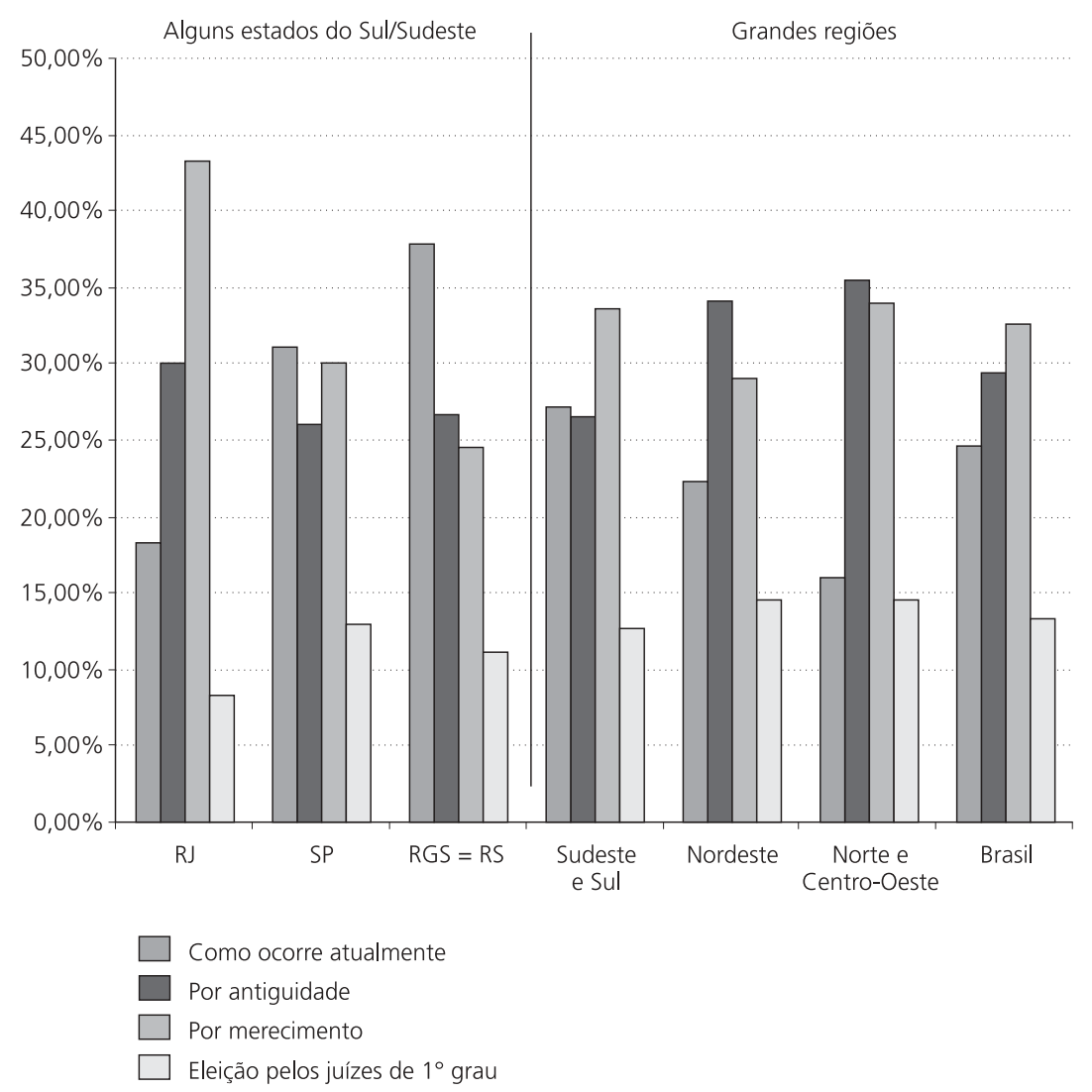

Fonte: Pesquisa "Perfil da M agistratura do Trabalho no Brasil".
21. Trabalhamos, em princípio, com a hipótese de queessa diferenciação pode, de um lado, refletir os efeitos da expansão ou estagnação econômica sobre o maior ou menor dinamismo dos processos sociais locais; de outro, expressariatambém certa "cultura cívica" envolvendo a qualidade das demandas dos movimentossociais, o alcance das articulações entre eles e deles com o Estado, o caráter da tradição jurídica, entre outros aspectos (cf. Putnam, 1996). 
22. $\mathrm{N}$ as entrevistas, os juízes destacavam, porém, que a promoção por merecimento deveria ocorrer com baseem critérios objetivos que envolvessem a avaliação do desempenho do juiz, a educação pós-graduada, cursosrealizadosetc.
Q uanto à promoção para os Tribunais Regionais do Trabalho, os juízes do N orte/C entro-O este (36\%) e N ordeste (34\%) preferem o critério de antiguidade, seguido pelo critério de merecimento (33\% e 28\%, respectivamente). N o Sudeste/Sul, entretanto, os juízes optam pela promoção por merecimento ${ }^{22}(35 \%)$, contra $25 \%$ pelo critério de antiguidade e $24 \%$ pelo sistema atual dealternância. D estaque se igual mente que, embora como opção menos votada, a possibilidade de que o conjunto de juízes de 1 - grau eleja aqueles a serem promovidos para os TRTs aparece com quase $15 \%$ das preferências do $\mathrm{N}$ orte/C entro- 0 este e do N ordeste, e $12,5 \%$ do Sudeste/Sul.

Já quanto à indicação dos ministros do TST, os juízes detodas as regiões concentram sua escolha no critério de eleição pela totalidade dos juízes (N ordeste, 62\%; N orte/C entro-O este, 61\%; Sudeste/Sul, 58\%). A segunda opção, no caso do Sudeste/Sul (pouco mais de 30\%) e do Nordeste ( $25 \%$ ), é pela preservação do sistema atual, enquanto no $\mathrm{N}$ orte/C entro0 este (20\%) prefere-se a eleição pelos próprios ministros.

GRÁFICO 9

O pinião sobre Promoção para oT ST por Região de Atuação

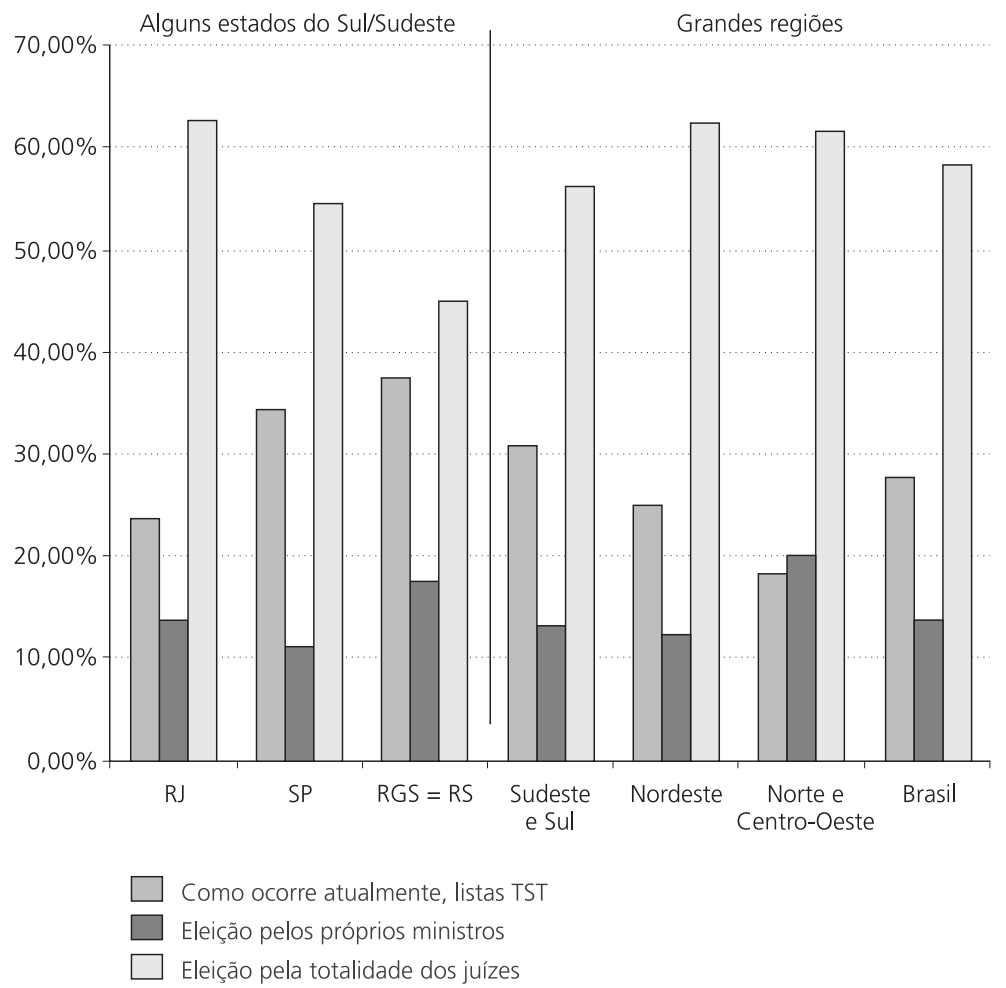

Fonte: Pesquisa "Perfil da M agistratura do Trabalho no Brasil". 
0 ambiente "externo", por sua vez, nem sempre é receptivo à ação da Justiça do Trabalho. Reconhecida pelos estratos populares, conforme de monstram algumas pesquisas (cf. Grynspan, 1999), como um dos espaços possíveis de exercício da cidadania em nosso país, esse ramo da justiça foi e continua sendo alvo das pressões liberais pela supressão de seu poder de intervenção a favor dos socialmente mais fracos, função que a maioria dos própriosjuízes (52\%) reconhece como especial mente relevante para o equilíbrio entre capital e trabalho, como demonstra o Gráfico 10.

\section{GRÁFICO 10}

Papel da Justiça do Trabalho por Grau de Importância

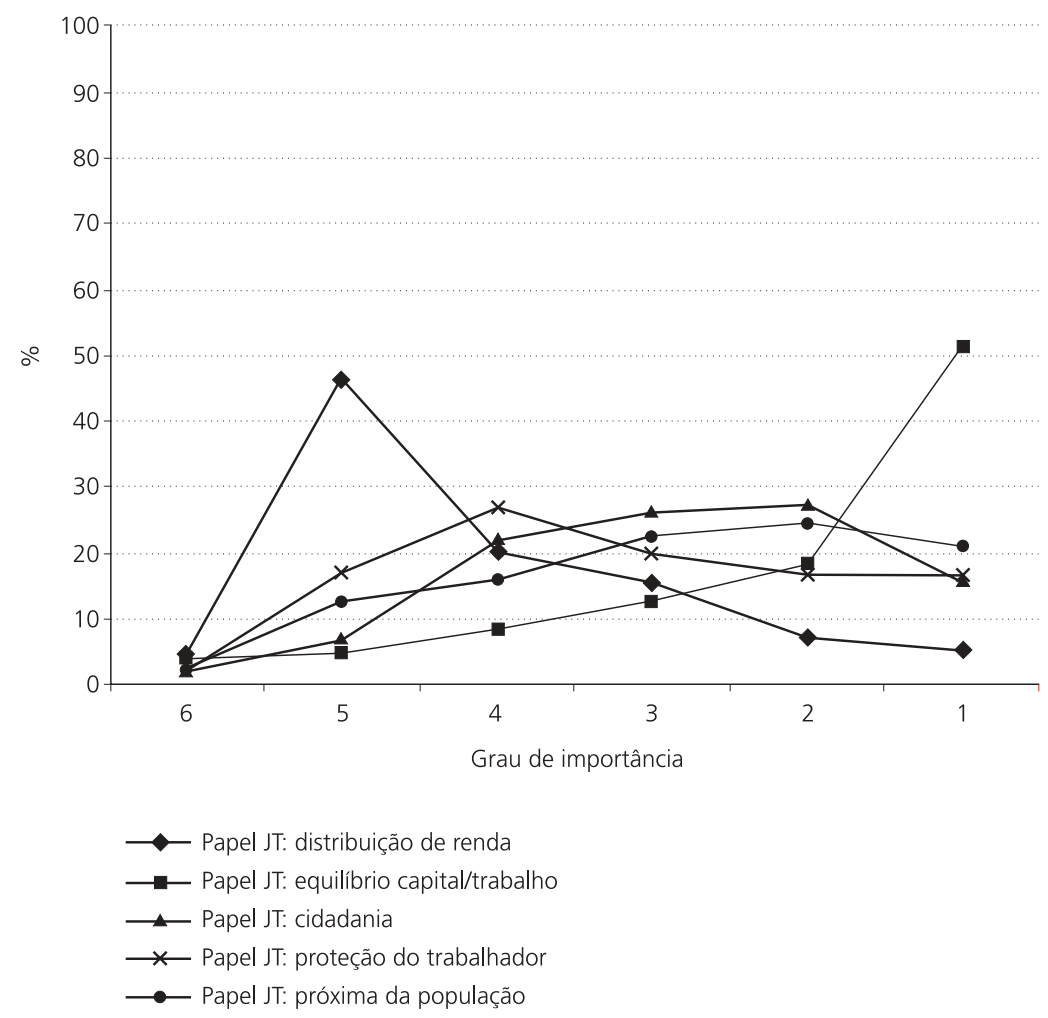

Fonte: Pesquisa "Perfil da M agistratura do Trabalho no Brasil".

Isso não significa, entretanto, que os juízes desconheçam os desafios postos pelos graduais avanços da democracia brasileira, nem pelas mudanças que, globalmente, continuam pressionando a reestruturação da produção capitalista e exigindo a reorganização do mundo do trabalho. O s magistrados consultados por nossa pesquisa admitem que muitos ajustes se fazem necessários, embora divirjam constantemente quanto às formas e aos ritmos dessas transformações. 
Em nosso survey procuramos registrar também as percepções dos juízes sobre temas referentes ao papel e ao desempenho da Justiça do Trabalho, bem como questões em pauta por força da Reforma do Judiciário e das possíveis reformas sindical e trabal hista.

Assim, pode-se perceber que os juízes estão primeiramentepreocupados em aprimorar o funcionamento da justiça eampliar o acesso a ela. A póiam, na sua grande mai oria, a ampliação da competência da Justiça do Trabal ho, introduzida pela Reforma do Judiciário, que propicia estender sua ação, antes restrita às relações de emprego, a todas as relações de trabal ho. Com isso, sinalizam seu interesse em atingir o trabal ho informal e outras relações igualmente, ou ainda mais, precárias de trabalho.

GRÁFICO 11

O pinião sobrea Ampliação da Competência da Justiça do Trabalho por Região deAtuação

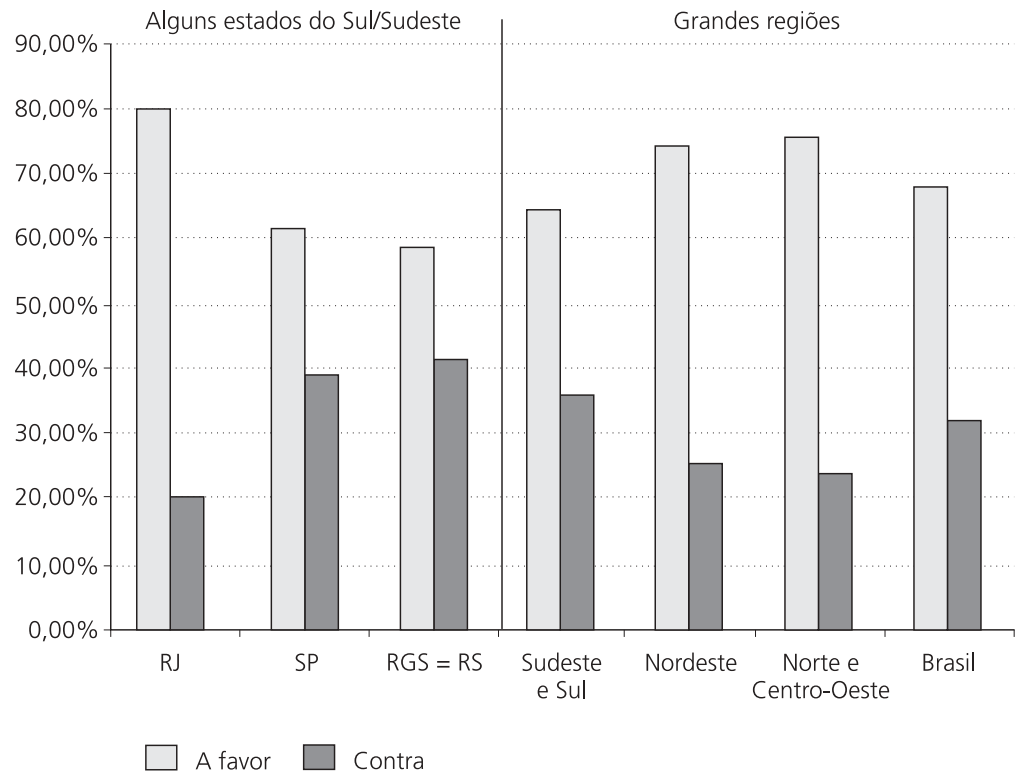

Fonte: Pesquisa "Perfil da M agistratura do Trabalho no Brasil".

No campo especificamente dos direitos coletivos, o item da Reforma do Judiciário que exige a concordância das duas partes envolvidas no conflito trabalhista (representadas pelos sindicatos de patrões e de trabalhadores) para a instauração de dissídios junto à Justiça do Trabalho - numa clara tentativa de dificultar o acesso a ela - foi apreciado predominantemente de forma negativa pelos magistrados. 
GRÁFICO 12

0 pinião sobre a Emenda n. 45 ( $D$ isś́di os Coletivos) por Região de A tuação

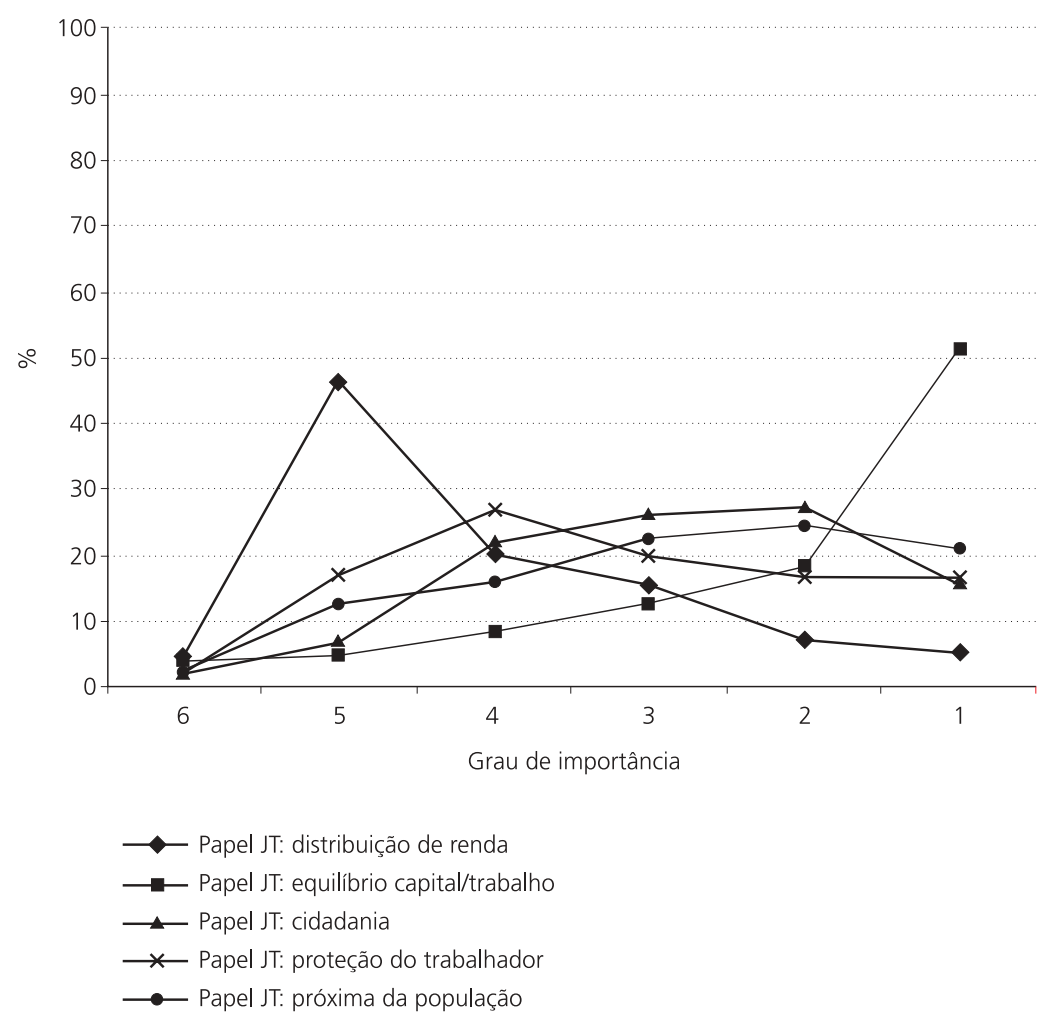

Fonte: Pesquisa "Perfil da M agistratura do Trabalho no Brasil".

O bserve-se que as respostas variaram de $65 \%$ no N ordeste a $54 \%$ no Sudeste/Sul. Q uanto aos estados, deve-se ressaltar que, embora as opiniões desfavoráveis também prevaleçam, o destaque vai para o Rio G rande do Sul (62\%), também o menos tolerante (6\%) diante da possível inconstitucionalidade do item restritivo ${ }^{23}$.

No que se refere, por outro lado, às medidas processuais adotadas para agilização das causas já existentes e efetividade do processo trabalhista, as opiniões são mais convergentes ${ }^{24}$. M ais de $70 \%$ dos magistrados ouvidos indicam a chamada penhora on-line ${ }^{25}$ como a medida de maior importância entre as introduzidas recentemente.

D o mesmo modo, sobre outros procedimentos que os juízes gostariam de ver implementados para melhorar o desempenho da Justiça do TrabaIho em termos processuais, o Gráfico 14 mostra a convergência de suas opiniões.
23. 0 SistemadeAcompanhamento das Contratações Coletivas SACC, do Dieese, regis tra que mesmo com a Emenda n. 45 e a exigência do acordo entre aspartesem conflito para ainstauração do disś́dio coletivo na Justiça do Trabalho, alguns tribunaistêm admitido ainstauração unilateral do dissídio, al egando "concordância tácita" se não hámanifestação dedaradadeumadas partes (cf. Dieese, 2006). D e toda forma, constatasequea taxa de intervenção da Justiça do Trabalho nos conflitos coletivos caiu vertiginosamente de 1993 a 2005, graças "a um processo decrescente rejeção do judiciário tra balhista a julgar o mérito dosdissídios coletivos" (Idem, p. 13), mesmo na 4a Região (Rio Grande do Sul), onde a taxa de "judicialização dos conflitos" alcançou 92,3\% em 1993-1994.

24. Todos os juízes ouvidos, nas diversas circunstâncias, avaliam que énafase da execução da sentença, ou seja, no momento em que da deve efetivar-seconcretamente, que reside o "nó" da eficácia dos processos da Justiça do Trabalho. 
25. A penhora on-line permite, em parceria com o Banco Central, o bloqueio imediato pelo juiz dos recursos bancários da parteexecutada, para assegurar o cumprimento da sentença e o rápido pagamento dos valores devidos. 0 utras medidas bastante votadas referem-se à concentração de atos processuais e à oralidade; à antecipação de tutela (que correspondeàliminar da justiça comum); à implementação de ações coletivas, ou seja, ações civispúblicas do M inistério Público do TrabaIho, nas varas. Além disso, há o procedimento sumaríssimo, para causas envolvendo menores recursosfinanceiros.
GRÁFICO 13

Grau de Importância das M edidas Processuais Introduzidas

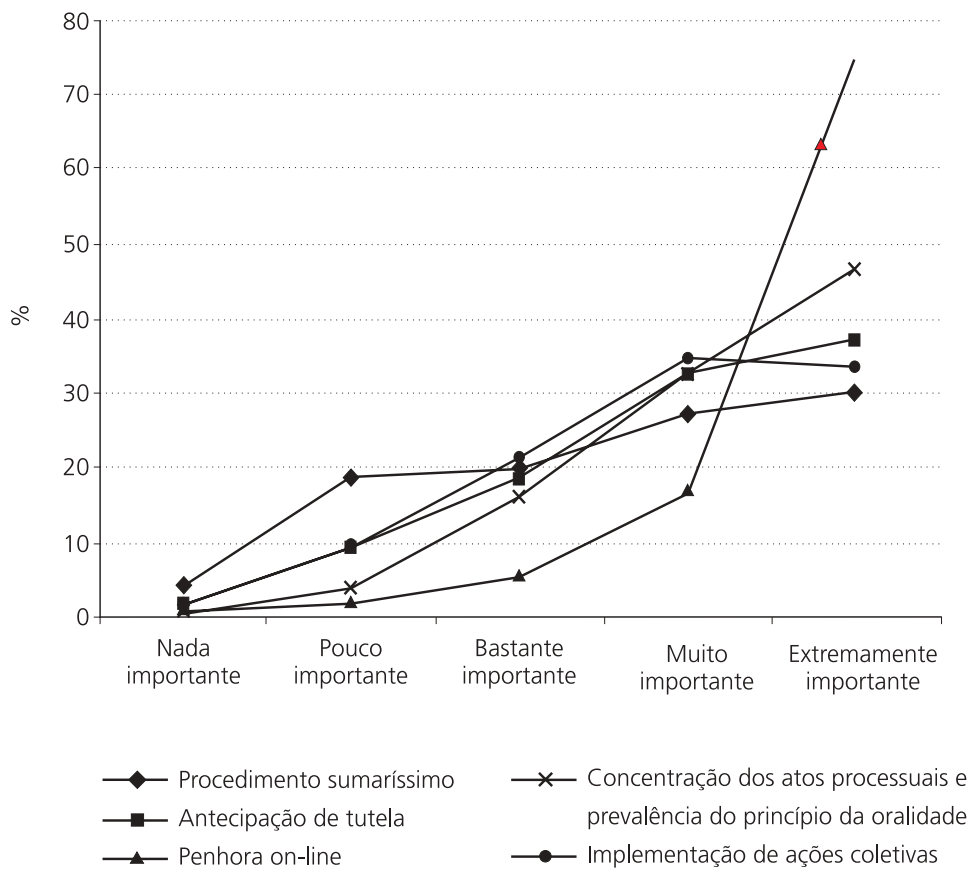

Fonte: Pesquisa "Perfil da M agistratura do Trabalho no Brasil".

GRÁFICO 14

O utros Procedimentos a ser Implementados para Aprimorar a Justiça do Trabalho

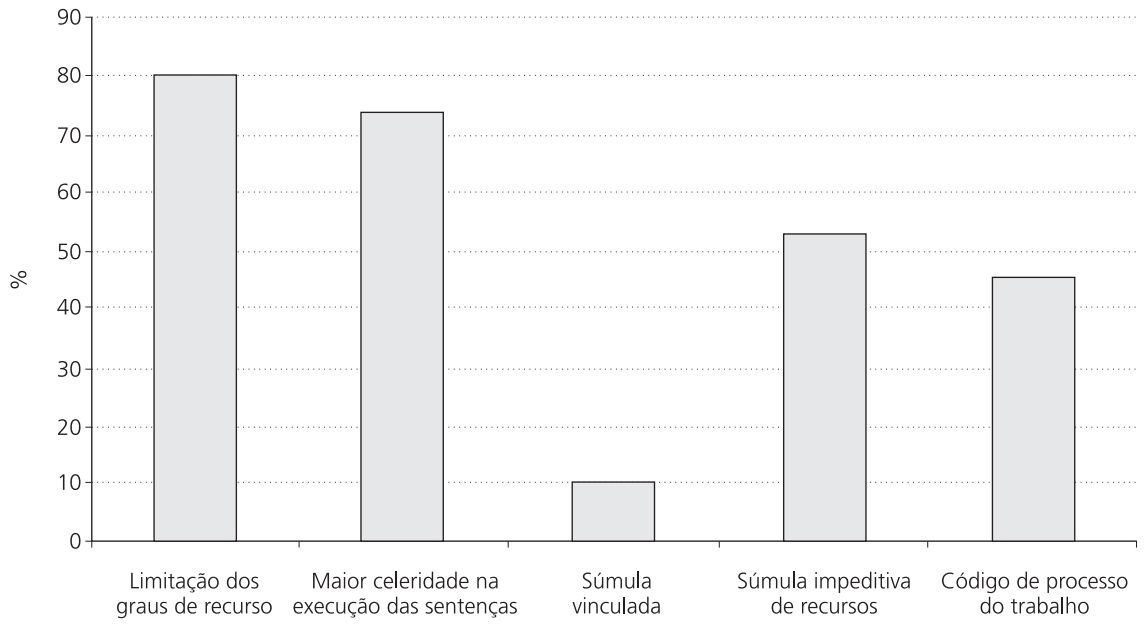

Fonte: Pesquisa "Perfil da M agistratura do Trabalho no Brasil". 
Como se pode observar, a preocupação em limitar os graus de recursos aos tribunais superiores é manifestada por $80 \%$ dos juízes, desejosos não só de maior celeridade na execução das sentenças ( $73 \%$ das respostas) como favoráveis à súmula impeditiva de recursos (mais de 50\% das respostas), nesteúltimo caso em contraponto à opção pela súmula vinculante, indicada por apenas $11 \%$ dos juízes ouvidos ${ }^{26}$.

A oportunidade de discutir a proposta de reforma sindical do Fórum N acional do Trabalho, por sua vez, permitiu explicitar que os juízes, apesar de tudo, sinalizam para a necessidade de construção de um cenário trabaIhista com maior autonomia dos atores envolvidos nos conflitos. N esse sentido, merecem destaque as opiniões dos juízes sobre dois temas importantes, indicadores de maior ou menor autonomia do movimento sindical em relação à tutela do Estado. Perguntados sobrea propriedade da cobrança do imposto sindical, menos de $20 \%$ dos juízes a defendem. Q uanto à pluralidade sindical, mais de $80 \%$ dos juízes a defendem.

GRÁFICO 15

O piniões sobre Algumas Q uestões

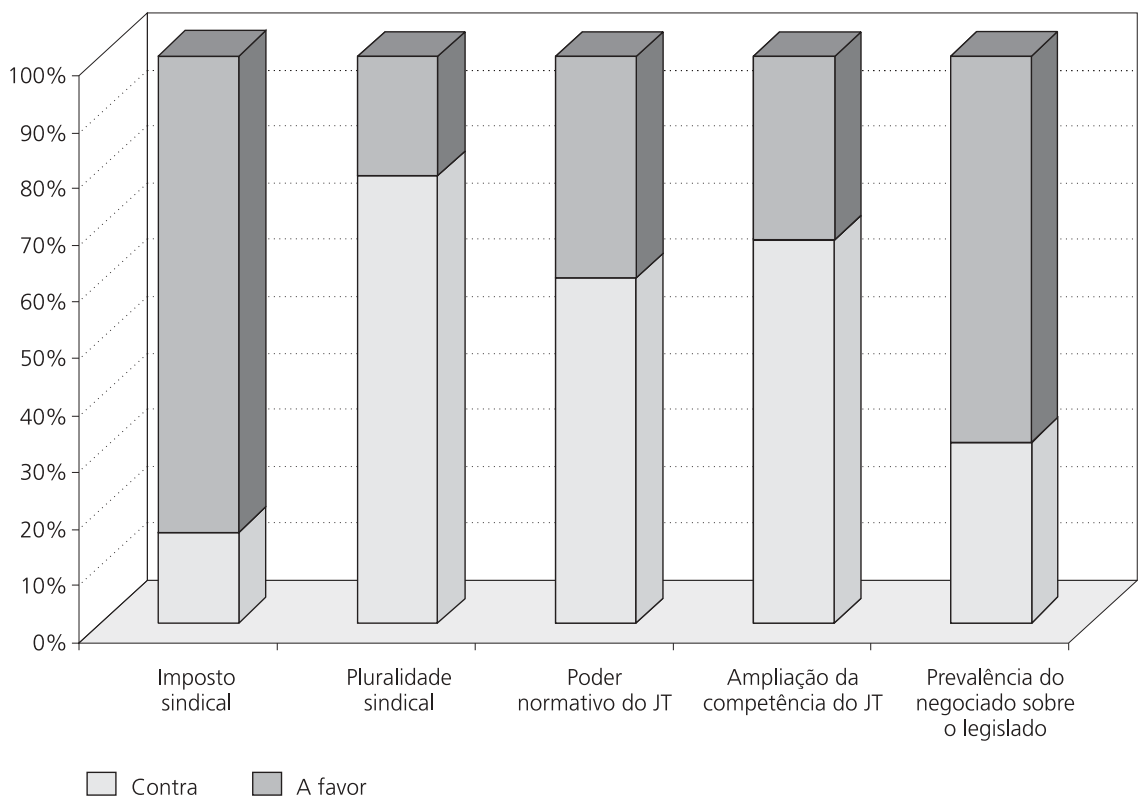

Fonte: Pesquisa "Perfil da M agistratura do Trabalho".

Tal postura não esconde, entretanto, a preocupação, claramenteindicada, com a preservação de um espaço significativo para o exercício do direito do
26. A finalidade das súmulas é a indicação decasosem quenão cabem recursos para os tribunais superioresem virtude da recorrência das decisões destes no mesmo sentido, garantindo assim processos maisrápidos. Já existem súmulas do TST, mas há projetos para aperfeiçoá-las eintroduzi-las desde a 10 instância, quando o juiz já impediria os recursos. A grande diferença é que a súmula vinculante, reunindo decisões dos tribunais, deve ser seguida pelosjuízes, o que não ocorreria com a súmula impeditiva de recursos. 
trabalho e a ação da justiça. Como também se pode ver no Q uadro 15, a manutenção do poder normativo da Justiça do Trabal ho éamplamente defendida pelos juízes, al cançando mais de $60 \%$ das respostas.

Essa posição se reforça, finalmente, diante dos desafios postosà Justiça do Trabalho, pelo estímulo formalizado - tanto na Reforma do Judiciário como na proposta dereformasindical - ànegociação coletiva entreosagentes do capital edo trabalho. Perguntados sobrea possível prevalência dos resultados da negociação coletiva (o "negociado") sobre o estabelecido na legislação traba Ihista (o "legislado"), os juízes revelaram mais uma vez uma convergência de posições (quase $70 \%$ das respostas). Paraeles, aliberdadepreconizada no campo das relações trabalhistas não deveprescindir da presença da Justiça do Trabal ho edeseusjuízes, guardiõesatentos na defesa dos direitos.

\section{Considerações finais}

Pode-se dizer que, a despeito da heterogeneidade marcante da origem social dos juízes do trabalho, o vigoroso associativismo da categoria tem contribuído para consolidar uma identidade coletiva, disseminando valores elinguagem em comum, partilhadospor eles. A Anamatra éhojereconhecida como porta-voz importante do coletivo de juízes do trabal ho na relação com o TST eo Consel ho $\mathrm{N}$ acional da Justiça do Trabal ho, bem como com os demais poderes. Sediada em Brasília, desenvolveu uma rede estruturada nacionalmente, compreendendo as 24 Amatras regionais, emantém diálogo permanente com associações semel hantes, especial mente com a Associação N acional dos Procuradores do Trabalho (AN PT). Em 2000, alterou-se seu estatuto para quese convertessenuma entidade nacional declasse, o que permite a ela ajuizar Ações D iretas de Inconstitucionalidade (Adins) e, assim, contestar decisões dos tribunais superiores. Em 2004, num gesto de forte impacto simbólico, o C onsel ho de Representantes da Anamatra decidiu pela desvinculação da Associação dos M agistrados Brasileiros (AM B).

27. D as 24 Amatras, sete decidiram permanecer ligadas à AM B.
Tal decisão, quenão foi unânime ${ }^{27}$, visou certamentea reforçar o movimento dediferenciação e afirmação deuma identidade própria de "juiz do trabaIho", distinta dos demais juízes.

O s dados apresentados mostram como as opiniões dos juízes convergem sobre várias questões relevantes. Preocupados em resguardar a função social da Justiça do Trabalho, os magistrados defendem a ampliação do acesso a ela, a manutenção de suas características particulares e as medidas que agilizem o processo e a execução das sentenças. 
As questões relativas à carreira deixam al guns vestígios de dissenso: nas diferentes regiões, os juízes divergem sobreos critérios vigentes de promoção decargos. M as quasetodos defendem a eleição pel o conjunto da magistratura como a melhor forma de escolha dos dirigentes dos tribunais, numa clara indicação de que a maioria dos respondentes, os juízes de varas, aspira a ampliar seu poder de intervenção sobre a orientação dos tribunais superiores.

Foi igualmente possível observar que, embora divergindo quanto às mudanças propostas ou em curso, por força de reformas presentes na atual agenda política, os juízes fatal mente aproximam suas opiniões no que se refere à defesa da legislação e ao papel de sua instituição nesse sentido. Assim, embora se diferenciem regional mente quanto a temas polêmicos da R eforma do Judiciário - como no caso da ampliação da competência e das novas regras para a instauração do dissídio coletivo - ou da proposta de reforma sindical - por exemplo os itens sobre imposto e unicidade sindical -, osmagistrados adiantam sua posição quase unificada contra as perspectivas de uma reforma trabalhista maisradical, em quea prevalência dos direitos definidos pela legislação trabal hista possa ser suplantada pel os resultados da negociação coletiva.

Por tudo isso talvez se possa afirmar, afinal, que a Justiça do Trabal ho e seus operadores vivem um período de bastante tensão em relação aos desafios externos, quanto ao seu desempenho e à redefinição de sua função social, diante das reincidentes pressões e efetivos avanços da lógica liberal, e aos vários desafios internos, relacionados a demandas de maior autonomia e participação por parte de sua base socialmente diferenciada e politicamente competitiva.

Redefinindo os papés dos atores envolvidos no conflito trabal hista, bem como as regras do jogo, as reformas recentes afetam direta ou indiretamente a Justiça do Trabalho. Assim, se de um lado a Reforma do Judiciário ampliou sua capacidade de atuação, de outro, as reformas sindical e trabaIhista poderão colocar em questão os limites daquela. 0 maior ou menor papel concedido ao Estado emais especificamente à justiça, o lugar atribuído à lei na hierarquia das normas sociais, o papel das instituições na configuração do mercado de trabalho e direitos de cidadania, o reconhecimento dos sindicatos como órgãos de representação legítima de interesses coletivos continuam se apresentando como dimensões centrais dessa disputa. 


\section{Referências Bibliográficas}

Bonelli, M aria da G loria. (2002), Profissionalismo e política no mundo do direito: as relações dos advogados, desembargadores, procuradores de justiça e del egados de polícia com o Estado. São Carlos, ED FSC ar/Fapesp/Idesp.

C ARD 0 So, Adal berto. (2002), "D ireito do trabal ho e relações de classe no Brasil contemporâneo". In: W ERn ECK VIAN NA, L uiz (org.). A democracia e osTrês Poderes no Brasil. Rio de Janeiro/Belo H orizonte, Iuperj/Faperj/Editora da U FM G.

Castro Gomes, Ângela M aria de. (1994), A invenção do trabalhismo. Rio de Janeiro, Relume-D umará.

Castro Gomes, Ângela M aria de, Pessanha, Elina G. da Fonte $\&$ M orel, Regina Lucia M . (2004). Arnaldo Sussekind: um construtor do direito do trabalho. Rio de Janeiro, Renovar.

. (2007), "Perfil da magistratura do trabalho no Brasil". In: CASTRo Gomes, Ângela M aria de (org.). D ireitos e cidadania: justiça, poder emídia. Rio de Janeiro, Editora FGV.

Dieese. (2006), Estudos e Pesquisas, ano 2, n. 21, jun.

Ferreira, Waldemar. (1938), Problema do direito corporativo. 2 ed. Brasília, Câmara dos D eputados.

Fragale, Roberto. (2006), "Três décadas de Anamatra: trabalho, justiça e cidadania como traços de uma identidade coletiva (ainda e sempre) em construção". C onsultado no site http://www.amatral.com.br/material/Anamatra_30.pdf, em 21/ $11 / 2006$.

GrYnSPAN, M ario. (1999), "Acesso e recurso à justiça no Brasil: algumas questões". In: Pandolfi, Dulce, Carvalho, José Murilo, Piquet Carneiro, Leandro \& Grynspan, M ario (orgs.). Cidadania, justiça e violência. Rio de Janeiro, Editora FGV.

M oraes Filho, Evaristo de. (1978), o problema do sindicato único no Brasil. São Paulo, Alfa Ô mega. . (1982), D irei to do trabalho: páginas da história e outros ensaios. São Paulo, LTr.

M orel, Regina L. M oraes \& Pessanha, Elina G. da Fonte. (2006), “M agistrados do trabalho no Brasil: entre a tradição ea mudança”. Estudos H istóricos, 31, jan.-jun., Rio de Janeiro, CPDOC/FGV.

M orel, Regina L. M oraes, Castro Gomes, Ângela \& Pessanha, Elina G. da Fonte. (2007), Sem medo da utopia: Evaristo de M oraes Filho, arquiteto da sociologia e do direito do trabalho no Brasil. São Paulo, LTr.

Putn Am, Robert. (1996), Comunidade e democracia: a experiência da Itália moderna. Rio de Janeiro, Editora FGV. 
SADEK, M aria Tereza. (2006), M agistrados: uma imagem em movimento. Rio de Janeiro, Editora FGV.

\section{Resumo}

Justiça do trabalho

0 artigo tem por objetivo destacar a especificidade da Justiça do Trabalho, assim como al gumas particularidades do perfil de seus magistrados. N ossas observações baseiam-se em resultados do projeto "H istória da justiça e dos direitos do trabalho no Brasil", voltado para a reconstituição da história da instituição principalmente por meio dos de poimentos de personagens centrais para sua construção e consolidação ao longo do tempo. Paralelamente, realizamos um abrangentesurvey em 2005 - "Perfil da magistratura do trabalho" -, enviando questionários para os cerca de 3 mil magistrados do trabalho do país, com a finalidade de traçar o perfil sociológico da categoria, assim como registrar suas percepções sobre a carreira e o papel desempenhado pela J ustiça do TrabaIho na sociedade brasileira. N ossas conclusões ressaltam a continuidade da forte marca antiliberal de proteção social pelo Estado, ainda presente na instituição e no ethos de seus operadores, e os desafios a serem enfrentados por eles perante a desigualdade social, o ambiente político democrático e as pressões econômicas do neoliberalismo. Palavras-chave: Justiça do Trabal ho; Juízes do trabal ho; D ireitos do trabalho; D ireitos sociais; Legislação trabalhista.

\section{Abstract}

Labor law in Brazil

Thepaper looks to highlight the specific nature of Labor Justice in Brazil, as well as the particular social profile of labor judges. $O$ ur analysis is based on the results of the research project "A history of labor law and labor rights in Brazil,' focused on reconstructing the history of this legal institution, mainly through interviews with social actors who played a central role in its construction and consolidation. The extensive information obtained from the 'Labor judge profile' survey also allowed us to identify thesociological profile of the judges and record their opinions about their professional career and the role played by Labor Courts in Brazilian society. O ur conclusions reveal the continuance of a strong anti-liberal logic of social protection by the State, still present in the institution and the ethos of its agents, and highlight the challenges these have to face in terms of social inequal ity, the democratic political order and neo-liberal economic pressures.

Keywords: Labor Law; Labor Judges; Labor Rights; Social Rights; Labor Legislation.
Texto recebido e aprovado em 27/9/2007.

ReginaLuciaM . M orel éprofessora do Progra ma de Pós-Graduação em Sociologia eAntropologia (PPGSA) da Universidade Federal do Rio de Janeiro. Email: regina.morel@ter ra.com.br.

Elina G. da Fonte Pes sanha é professora do Programa de Pós-Gra duação em Sociologiae Antropologia (PPGSA) da Universidade Federal do Rio deJaneiro. Email: elina.pessanha@te rra.com.br. 